\title{
Determination of Water Quality Status of Telaga Menjer Wonosobo, Indonesia: An Official Tool for Evaluating the Best Function of Water
}

\author{
Nur Arina Firmahaya', Agatha Sih Piranti ${ }^{2 *}$ \\ 1 Post Graduate of Department of Environmental Science, Jenderal Soedirman University, Unsoed, Purwokerto, \\ Indonesia \\ 2 Department of Environmental Biology, Biologi Faculty, Jenderal Soedirman University, Unsoed, Purwokerto, \\ Indonesia \\ * Corresponding author's e-mail: agatha.piranti@unsoed.ac.id
}

\begin{abstract}
Human activities may cause degradation of water quality. For monitoring purpose, it is necessary to know the level of pollution that occurs in water in order to sustain the function of the aquatic ecosystem. The purpose of this study was to determine the level of water pollution of Menjer Wonosobo Lake based on the physical, chemical, and biological parameters to evaluate the best function of the water to support the human activities. The study was conducted for three months (July to September 2020). Water sampling was carried out at seven stations; then, the measurement results were compared with the water quality standards based on Government Regulation No. 22 of 2021. Determination of water quality was carried out using the STORET method. The results showed that there were 7 parameters that exceeded the water quality standards, namely TSS, BOD, COD, DO, N, P and Coliform. The status of water quality was at a moderately polluted level and only functions for the needs of category 3 , i.e. for freshwater fish cultivation, for irrigating plants, and or other purposes. Therefore, it was necessary to manage Menjer Lake to improve its water quality.
\end{abstract}

Keywords: Menjer lake, STORET, water quality.

\section{INTRODUCTION}

Menjer Lake is a lake formed by the eruption of Mount Pakuwaja. This lake is located at an altitude of 1,300 above sea level, namely in the Maron Village, Garung District, 12 kilometers north of the city of Wonosobo, Central Java Indonesia. In the rainy season, this lake occupies a basin area of 70 hectares with a water depth of 45 meters. However, outside of the rainy season, the water level drops to 20 meters (Kumalasari et al., 2015).

Menjer Lake is used by local residents for tourism, agricultural irrigation, and floating net cages (Kumalasari et al., 2015). In addition, since 1982 it has been used as a Hydroelectric Power Plant. This hydropower plant produces $48 \mathrm{GWh}$ of electricity per year, on average (Amalia, 2016). The sustainability of the ecosystem function of
Menjer Wonosobo Lake needs to be considered in terms of the benefits for the surrounding community in meeting the needs of life. However, human activities often cause water pollution. Therefore, it is necessary to know the level of pollution that occurs in the waters of Menjer Lake (Suharto et al., 2019). According to Law of the Republic of Indonesia No. 32 of 2009 concerning Environmental Protection and Management, pollution means the entry and inclusion of living things, substances, energy, and/or other components into the environment by human activities so that they exceed the established environmental quality standards. Meanwhile, the environmental quality standard is a measure of the limit or level of living things, substances, energy, or existing components/polluting elements the existence of which is tolerated in a certain resource as an element of the environment. On the basis of the Government Regulation 
of the Republic of Indonesia Number 22 of 2021 concerning Water Quality Management and Water Pollution Control, the water quality status is the level of water quality conditions that indicate polluted conditions or good conditions in a water source within a certain time by comparing with the water quality standards set. Classification of water quality or water pollution level is set into four classes, namely first class for drinking water quality standards, second class for water recreation quality standards, freshwater fish farming, animal husbandry, and agriculture, third class for freshwater fish farming and agriculture, and fourth grade for agricultural irrigation. Human activities tend not to pay attention to the function of aquatic ecosystems (Purboseno, 2014). The changes in land use due to development pressures worsen the condition of waters. This is the main cause of the decline in water quality so that it interferes with the water allocation of Menjer Lake. Therefore, the purpose of this study was to assess the water quality of Menjer Lake and determine its status. Determination of the water quality status of Menjer Lake is very important to be used as a reference for environmental practitioners and policy makers in an effort to minimize pollution, preserve and maintain the ecosystem function of Lake Menjer Wonosobo through limiting the human activities in the waters of Menjer Lake so that its function continues to run but the pollution status can be minimized.

\section{MATERIAL AND METHODS}

The research was conducted using a survey method in the waters of Menjer Lake. Water sampling was carried out at seven stations covering the tourism area, the floating net cage area, the agricultural area, the middle area of the lake, the spring area, the inlet area of the Serayu River, and the outlet area. Determination of stations was performed via purposive sampling which represents the entire ecosystem of the lake. Sampling was carried out three times for three months (July, August and September, 2020) with an interval of once a month. The schematic for the location of water sampling is presented in Figure 1.

The data taken include physical data (temperature, TDS and TSS), chemical data ( $\mathrm{pH}, \mathrm{DO}$, BOD, COD, N and P), and biology (Total Coliform). The data obtained was in the form of in situ parameter measurement data (temperature,
$\mathrm{pH}$ ), and the data obtained through laboratory tests of each sample taken from each station. The sampling of water from each station was carried out during the day using a water sampler on the surface of the lake waters $(20 \mathrm{~cm}$ deep) as much as one liter and placed in a sample bottle. The water samples from the field were analyzed in the Wahaya Semarang laboratory.

In order to determine the status of water quality, the STORET method was used, referring to the Decree of the Minister of the Environment Number 115 of 2003. In principle, the STORET method is to compare the water quality data obtained with the adjusted quality standard to determine the status of water quality. Through the STORET method, the parameters that meet and exceed the water quality standards can be known. The calculation of the STORET method classifies water quality into four classes; Class A is very good, score of 0 (meets the quality standard), Class B is good, score of -1 to -10 (lightly polluted), Class $C$ is moderate, score of -11 to -30 (moderately polluted), and Class D is bad, score of $>-31$ (heavily polluted).

Determination of the water quality status using the STORET method is carried out with the following steps: first step is by comparing the measurement data of each water parameter with the value of the quality standard according to the water class. If the measurement results meet the quality standard value (measurement result $<$ quality standard), then it is given a score of 0 .

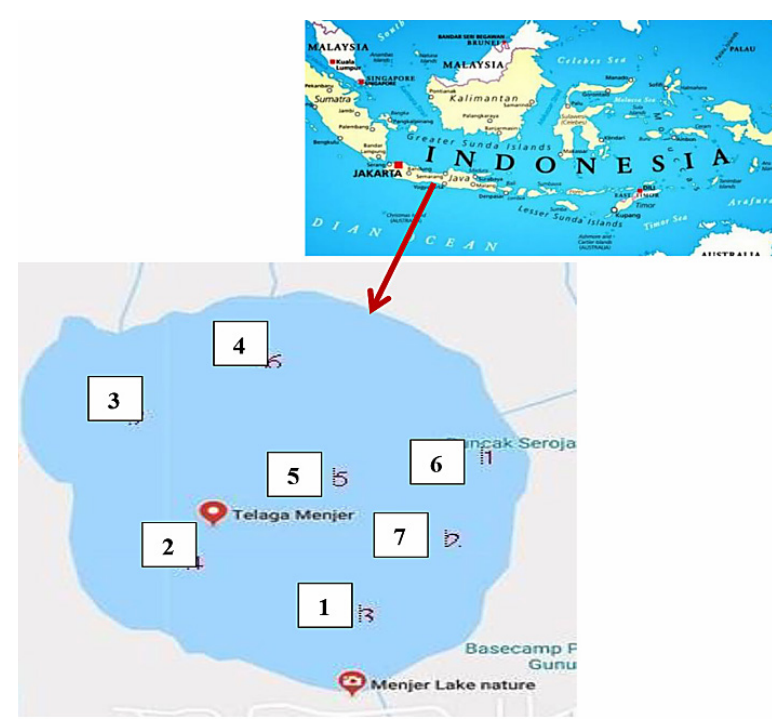

Figure 1. Sampling stations (Google Maps, 2020): 1) tourist, 2) flouting net cage,

3) agriculture, 4) middle, 5) water springs, 6) inlet of Serayu river, 7) outlet 
Moreover, if the measurement results do not meet the water quality standards (measurement results $>$ quality standards) then a score is given according to the parameter group and the amount of data as shown in Table 1.

Determination of water class is done by comparing the concentration of water quality parameters as stated in Government Regulation No. 22 of 2021 compared to the water quality standards for class I, class II, class III and class IV for each of these parameters. Water quality classification is set into 4 (four) classes. Class I is the water that can be used for drinking raw, and or other designations that require the same quality as that use. Class II is the water that can be used for water recreation infrastructure or facilities, freshwater fish cultivation, animal husbandry, water for irrigating crops, and or other designations that require the same quality as those uses. Class III is the water that can be used for freshwater fish cultivation, animal husbandry, water for irrigating crops, and or other designations that require the same for that use. In turn, Class IV is the water that can be used to irrigate crops, and or other uses that require the same quality as that use.

Table 1. Determination of value system to determine water quality status

\begin{tabular}{|c|c|c|c|c|}
\hline $\begin{array}{c}\text { Number } \\
\text { of } \\
\text { samples }\end{array}$ & \multirow{2}{*}{ Score } & \multicolumn{3}{|c|}{ Parameter } \\
\cline { 3 - 5 } & & Physics & Chemical & Biology \\
\hline \multirow{3}{*}{$<10$} & Maximum & -1 & -2 & -3 \\
\cline { 2 - 5 } & Minimun & -1 & -2 & -3 \\
\cline { 2 - 5 } & Average & -3 & -6 & -9 \\
\hline \multirow{3}{*}{$>10$} & Maximum & -2 & -4 & -6 \\
\cline { 2 - 5 } & Minimum & -2 & -4 & -6 \\
\cline { 2 - 5 } & Average & -6 & -12 & -18 \\
\hline
\end{tabular}

\section{RESULTS AND DISCUSSION}

The level of water pollution is based on the number of pollutant elements contained in the waters and is determined as the water quality standard value. If the amount of pollutant has exceeded the specified quality standard, it means that its presence can cause harm to living things that use the waters (Piranti et al., 2018).

The water quality status of Menjer Lake at the time of the study, when compared with class I and II water quality standards, showed that at all stations the condition was heavily polluted, but when compared to classes III and IV, it showed that at all stations the conditions were moderately polluted and met standard (Table 2). This shows that Menjer Lake water is not suitable if used for class I and II, as a raw source of drinking water and recreational water, but is said to be feasible if used for class III and IV for aquaculture and irrigating crops.

On the basis of the STORET analysis, it was shown that there are 7 parameters that exceed the water quality standards, namely TSS, BOD, COD, DO, N, P and Coliform, as shown in the following Table 3.

The concentration of Total Suspended Solid (TSS) at all stations is already high, ranging from 143.38 to $190.28 \mathrm{mg} / 1$. This shows that it has exceeded the water quality standards for classes I, II, and III, but is below the water quality standards for class IV (Figure 2.). On the basis of the TSS concentration, Menjer Lake is still suitable if used to irrigate crops, but it is not suitable for drinking water, recreational water needs, or cultivation purposes.

Table 2. Water quality status of Menjer Lake based on STORET Index

\begin{tabular}{|c|c|c|c|c|c|c|c|c|}
\hline \multirow{2}{*}{ Station } & \multicolumn{2}{|c|}{ Class I } & \multicolumn{2}{c|}{ Class II } & \multicolumn{2}{c|}{ Class III } & \multicolumn{2}{c|}{ Class IV } \\
\cline { 2 - 8 } & $\begin{array}{c}\text { STORET } \\
\text { Index }\end{array}$ & $\begin{array}{c}\text { Water quality } \\
\text { status }\end{array}$ & $\begin{array}{c}\text { STORET } \\
\text { Index }\end{array}$ & $\begin{array}{c}\text { Water quality } \\
\text { status }\end{array}$ & $\begin{array}{c}\text { STORET } \\
\text { Index }\end{array}$ & $\begin{array}{c}\text { Water quality } \\
\text { status }\end{array}$ & $\begin{array}{c}\text { STORET } \\
\text { Index }\end{array}$ & $\begin{array}{c}\text { Water quality } \\
\text { status }\end{array}$ \\
\hline 1 & -62 & $\begin{array}{c}\text { heavily } \\
\text { polluted }\end{array}$ & -54 & $\begin{array}{c}\text { heavily } \\
\text { polluted }\end{array}$ & -15 & $\begin{array}{c}\text { moderately } \\
\text { polluted }\end{array}$ & 0 & meet standard \\
\hline 2 & -60 & $\begin{array}{c}\text { heavily } \\
\text { polluted }\end{array}$ & -58 & $\begin{array}{c}\text { heavily } \\
\text { polluted }\end{array}$ & -15 & $\begin{array}{c}\text { moderately } \\
\text { polluted }\end{array}$ & 0 & meet standard \\
\hline 3 & -62 & $\begin{array}{c}\text { heavily } \\
\text { polluted }\end{array}$ & -62 & $\begin{array}{c}\text { heavily } \\
\text { polluted }\end{array}$ & -15 & $\begin{array}{c}\text { moderately } \\
\text { polluted }\end{array}$ & 0 & meet standard \\
\hline 5 & -60 & $\begin{array}{c}\text { heavily } \\
\text { polluted }\end{array}$ & -50 & $\begin{array}{c}\text { heavily } \\
\text { polluted }\end{array}$ & -15 & $\begin{array}{c}\text { moderately } \\
\text { polluted }\end{array}$ & 0 & meet standard \\
\hline 6 & -60 & $\begin{array}{c}\text { heavily } \\
\text { polluted }\end{array}$ & -52 & $\begin{array}{c}\text { heavily } \\
\text { polluted }\end{array}$ & -15 & $\begin{array}{c}\text { moderately } \\
\text { polluted }\end{array}$ & 0 & meet standard \\
\hline 7 & -60 & $\begin{array}{c}\text { heavily } \\
\text { polluted }\end{array}$ & -50 & $\begin{array}{c}\text { heavily } \\
\text { polluted }\end{array}$ & -15 & $\begin{array}{c}\text { moderately } \\
\text { polluted }\end{array}$ & 0 & meet standard \\
\hline
\end{tabular}


Table 3. The measurement of water quality compared to water quality standards

\begin{tabular}{|c|c|c|c|c|c|c|c|}
\hline \multirow{2}{*}{ No } & \multirow{2}{*}{ Parameter } & \multirow{2}{*}{ Unit } & \multirow{2}{*}{ Concentration } & \multicolumn{4}{|c|}{ Quality standards } \\
\hline & & & & Class I & Class II & Class III & Class IV \\
\hline 1 & TSS & $\mathrm{mg} / \mathrm{l}$ & $143.38-190.28$ & 25 & 50 & 100 & 400 \\
\hline 2 & BOD & $\mathrm{mg} / \mathrm{l}$ & $4.58-5.22$ & 2 & 3 & 6 & 12 \\
\hline 3 & COD & $\mathrm{mg} / \mathrm{l}$ & $22.24-25.29$ & 10 & 25 & 40 & 80 \\
\hline 4 & DO & $\mathrm{mg} / \mathrm{l}$ & $3.53-3.84$ & 6 & 4 & 3 & 1 \\
\hline 5 & $\mathrm{~N}$ & $\mathrm{mg} / \mathrm{l}$ & 4.47-8.49 & 0.65 & 0.75 & 1.90 & - \\
\hline 6 & $\mathrm{P}$ & $\mathrm{mg} / \mathrm{l}$ & $0.22-0.29$ & 0.01 & 0.03 & 0.1 & - \\
\hline 7 & Coliform & $/ 100 \mathrm{ml}$ & $2,100-6,100$ & 1,000 & 5,000 & 10,000 & 10,000 \\
\hline
\end{tabular}

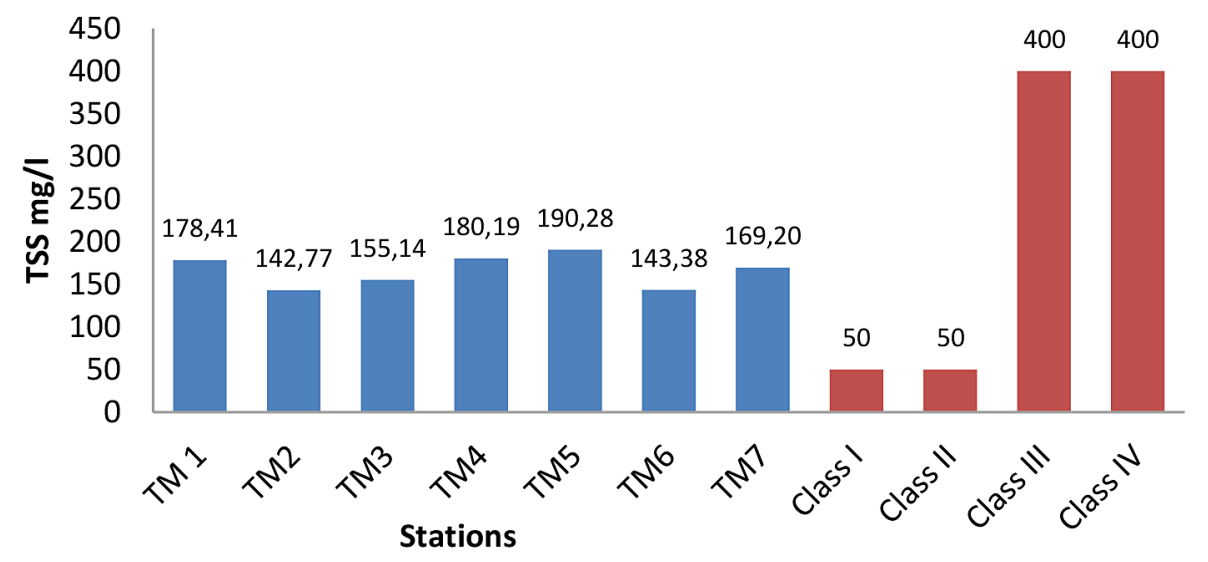

Figure 2. Distribution of TSS compared to water quality standard

Total Suspended Solid (TSS) is a suspended material retained in a milli-pore sieve with a pore diameter of $0.45 \mathrm{~m}$. TSS consists of mud, fine sand and micro-organisms caused by soil erosion carried into water bodies (Nurfatimah et al., 2019). In addition, TSS can also come from human activities, especially household activities, waste originating from the agricultural, livestock, and industrial sectors (Rahayu et al., 2018). The high TSS is due to the increase in organic matter sourced from domestic waste, fish metabolism and feed residue that accumulates in the waters (Muthifah et al., 2018). TSS can increase the value of turbidity, so that it affects the penetration of sunlight into the waters. This affects the process of photosynthesis of aquatic plants which will further reduce the supply of dissolved oxygen and increase the supply of $\mathrm{CO}_{2}$ in the waters (Azizah, 2017).

Chemical Oxygen Demand (COD) and Biochemical Oxygen Demand (BOD) are measures of the amount of organic matter in a waters (Daroini and Arisandi, 2020). Waters are indicated to be polluted by organic matter if they have high COD and/or BOD values or exceed the water quality standard limits (Christiana et al., 2020). COD is the oxygen requirement for the chemical decomposition of organic matter, while BOD is the amount of dissolved oxygen required by microorganisms to decompose organic matter under aerobic conditions (Santoso, 2018). The high COD and/or BOD in water bodies is caused by the anoxide condition at the bottom of the water which describes the slow decomposition process of organic matter at the bottom of the waters.

According to Pujiastuti et al. (2013), residual metabolism in fish and feeding fish using pallets can increase the COD value caused by the accumulation of organic matter in the waters. In turn, the high BOD in waters is due to the amount of oxygen needed by microbes to oxidize organic matter in high waters (Tatangindatu et al., 2011).

The COD concentration in Menjer Lake ranges from 22.24 to $25.29 \mathrm{mg} / \mathrm{l}$. This shows that it has exceeded the water quality standards for classes I and II, but is below the water quality standards for classes III and IV (Figure 3.). On the basis of the COD concentration, Menjer Lake is still suitable when used for cultivation and irrigating crops, but is not suitable for drinking water and recreational water needs. 
The BOD concentration in Menjer Lake ranged from 4.58 to $5.22 \mathrm{mg} / \mathrm{l}$. This shows that it has exceeded the class I and II water quality standards, but is below the class III and IV water quality standards (Figure 4). On the basis of the BOD concentration, Menjer Lake is still suitable when used for cultivation and irrigating crops, but is not suitable for drinking water and recreational water needs.

A high BOD value in a water indicates that the water has been polluted by organic matter. The activity of floating net cages in the waters of Menjer Lake is one of the causes of the high BOD in the Menjer Lake waters.
The DO concentration in Menjer Lake ranges from 3.53 to $3.84 \mathrm{mg} / \mathrm{l}$. This shows that it is not in accordance with the water quality standards of class I and II, but is still in accordance with the water quality standards of class III and IV (Figure 5). On the basis of theDO concentration, Menjer Lake water is still suitable when used for cultivation and irrigating crops, but not suitable for drinking water and recreational water needs.

The content of dissolved oxygen (Dissolved Oxygen) plays a role in determining the number of organisms in a water (Soliha et al., 2016). The higher the BOD and COD values, the lower the DO value (Muthifah et al., 2018). The low

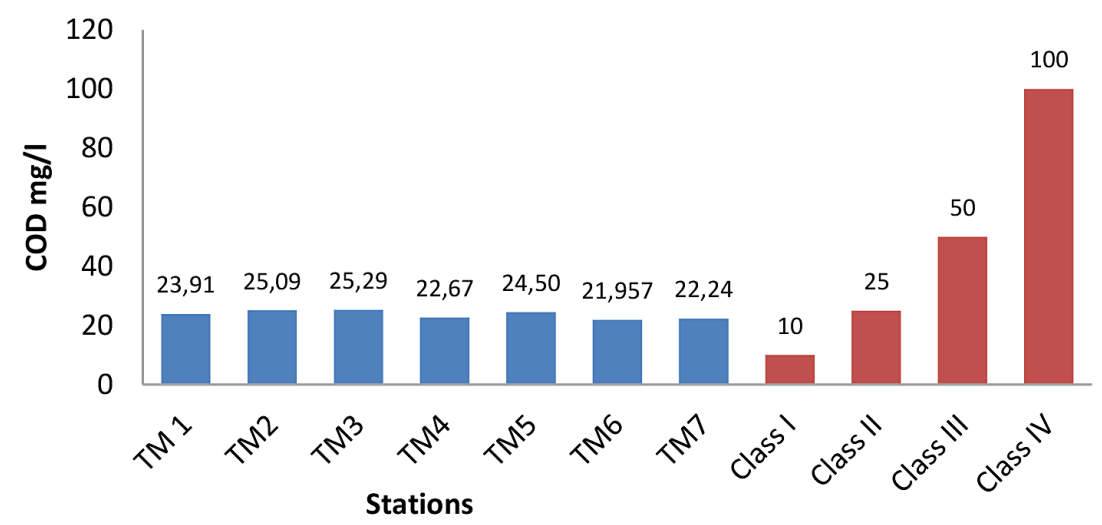

Figure 3. Distribution of COD compared to water quality standard

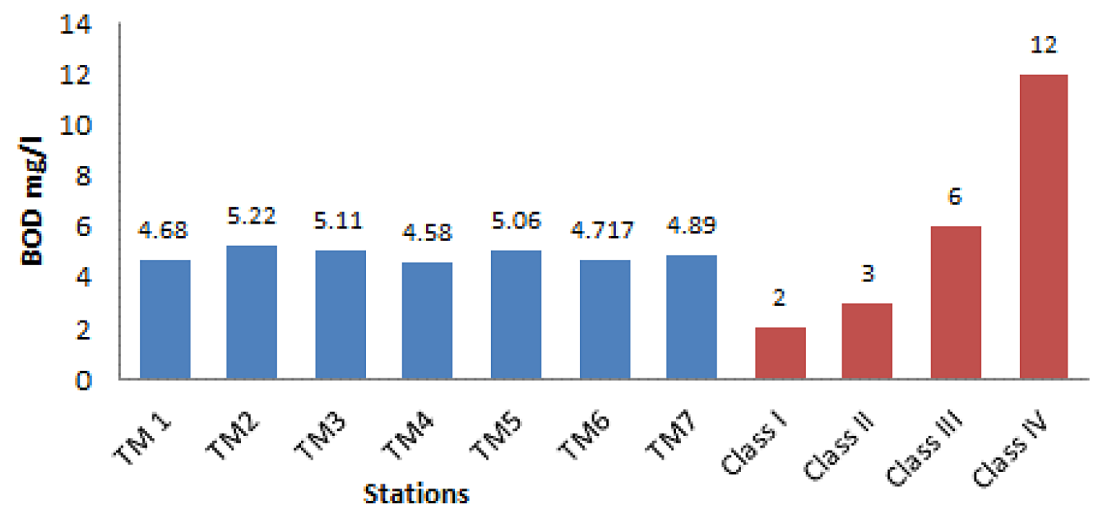

Figure 4. Distribution of BOD compared to water quality standard

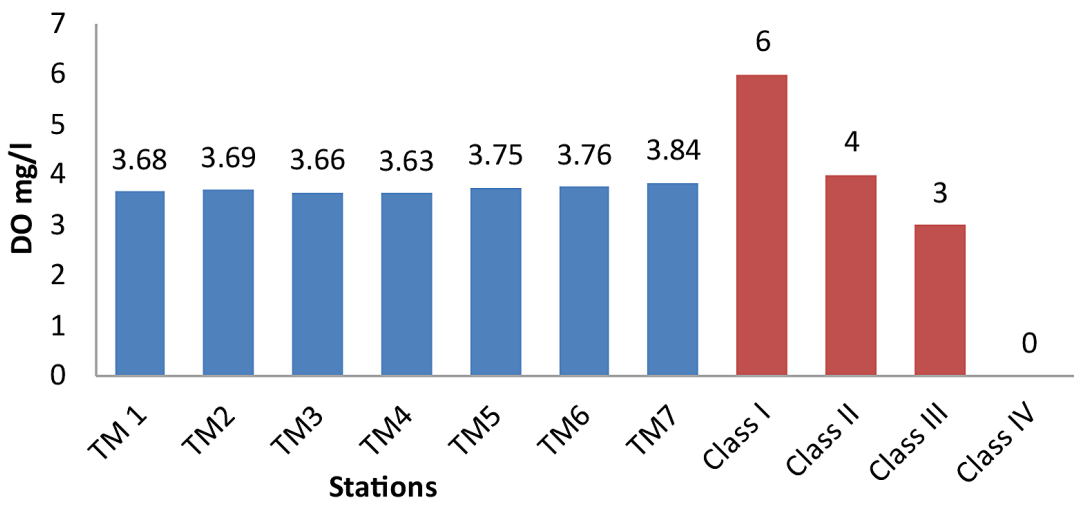

Figure 5. Distribution of DO compared to water quality standard 
DO value is due to the entry of household waste and fish farming using floating net cage activity which triggers an increase in organic matter in the waters so that it requires a lot of oxygen to carry out the decomposition process. The decrease in dissolved oxygen as a result of organic waste can reduce the efficiency of oxygen uptake for aquatic biota, thereby reducing their ability to live normally. (Anas et al, 2017).

The TN concentration obtained from the Menjer Lake water sample test ranged from 4.47 to $8.49 \mathrm{mg} / 1$ (Figure 6).

On the basis of Figure 3.5. it was shown that the concentration of TN has exceeded the class I, II and III water quality standards (Class IV is not defined). This means that based on the total P content, the water from the lake in all locations has exceeded the quality standards required for classes I, II, III, and the water was satisfy for sctandard for class IV.

The high level of TN in a waters is influenced by several factors. One of the most influencing factors is the presence of leftover feed from cultivation and the large number of residential areas in the catchment area (Alfionita et al., 2019). According to Putri et al. (2014), floating net cage contributes nitrogen in waters, namely in the form of uneaten feed residue, fish feces, and fish metabolic waste in the form of ammonia and urea.

The TP concentration in Menjer Lake is in the range of $0.22-0.29 \mathrm{mg} / \mathrm{l}$. This shows that it has exceeded the class I, II and III water quality standards (Class IV is not defined). This means that based on the total P content, the water from the lake in all locations has exceeded the quality standards required for classes I, II, III, and the water satisfied the standard for class IV (Figure 7).

The high content of TP in Telaga Menjer may be caused by the activities in the lake such as fish cultivation using floating net cage, and the lake border area which is supposed to be a conservation area but is planted with agricultural crops such as chili, corn, long beans and fertilization is also carried out. The catchment area of Telaga Jerger is located in the mountainous area of Dieng Wonosobo, which is in a very poor condition due to the conversion of land from forest to agricultural land, thereby increasing the

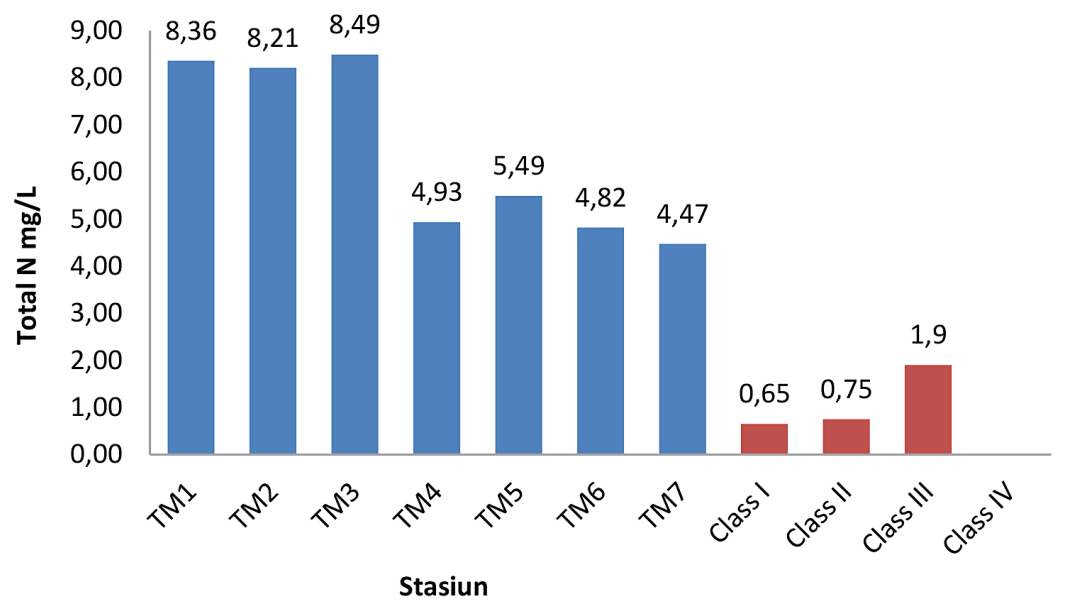

Figure 6. Distribution of $\mathrm{N}$ compared to water quality standard

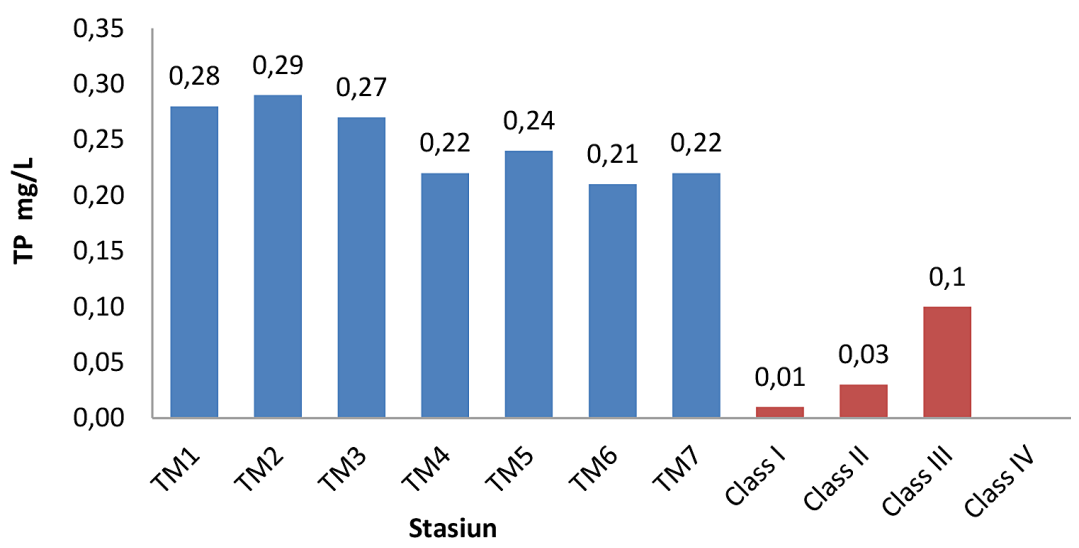

Figure 7. Distribution of $\mathrm{P}$ compared to water quality standard 
concentration of lake nutrients. This condition triggers the occurrence of microcystis blooms in the lake (Piranti et al, 2021).

The reduction in the concentration of Total $\mathrm{P}$ can be done by limiting the human activities in the catchment which can be a source of $P$ in the waters, for example excessive use of fertilizers, and floating net cage activity on the lake. Total phosphorus input from catchment area to lake will cause the eutrophication conditions. Eutrophication is the enrichment of waters, especially by nitrogen and phosphorus, causing uncontrolled growth of algae and aquatic plants. The source of nitrogen and phosphorus mainly comes from agricultural fertilizers, fisheries, and household waste. The most obvious effects of eutrophication is the blooming of algae and aquatic plants. $\mathrm{P}$ reduction can be done by limiting human activities in the catchment area such as excessive use of fertilizers, domestic activities and industrial waste (Piranti et al, 2021).

Eutrophication is the enrichment of waters by nutrients, especially nitrogen and phosphorus, resulting in uncontrolled growth of aquatic plants (Nopiantari et al., 2017). The impact of the abundance of aquatic plants causes the water quality problems to decrease (Piranti et al, 2021). The main sources of nitrogen and phosphorus mainly come from agricultural activities, fisheries, industry, and household waste (Alfionita et al., 2019).

Water quality indicators are also based on biological parameters, namely the total number of coliform bacteria that exceeds $1,000 / 100 \mathrm{ml}$ for class I water quality standards, $5,000 / 100 \mathrm{ml}$ for class II water quality standards, and 10,000/100 $\mathrm{ml}$ for class III and IV water quality standards. Coliform bacteria do not cause disease, but can indicate that disease-causing organisms can be present in water. Coliform bacteria can be found in the environment, such as in soil and water that has been affected by surface water and human and animal waste (Mokodampit et al., 2020). During rain, water will carry human and animal waste which seeps into the ground or flows into water sources (Sumampouw, 2017). Coliform bacteria can be used as an indicator of fecal contamination or human and animal waste in the waters (Lihawa and Mahmud, 2017).

Water quality indicators are also based on parameters biology, namely the total number of coliform bacteria not to exceed $1000 / 100 \mathrm{ml}$ for BMA class 1 water, 5,000/100 $\mathrm{ml}$ for Class II standard, and 10,000/100 $\mathrm{ml}$ for the standard of Class III and IV. Coliform bacteria do not cause disease. However, their presence in water indicates that disease-causing organisms (pathogens) can be present in the water system. During observation, the number of coliform bacteria contained in the Menjer Lake water was about 2,100/100 ml $-6.100 / 100 \mathrm{ml}$ (Figure 8).

On the basis of Table 8. when it was compared with the designation standard, then stations 6 (inlet from Serayu River) and 7 (Telaga Menjer outlet, intake power generation) are still quite good (below standard of class II). At the other stations it has exceeded the class II, although it is still below the class III.

The summary of water quality status based on the parameters that exceed the appropriate standard its designation is shown in Table 4.

Table 4 shows that Lake Menjer could not satisfy to the BMA class I and II, only meeting the standard of Class III and IV. This meant that the water of Menjer Lake was not feasible if used as raw water for drinking water and water recreation, but can only be used for fisheries and irrigation. There were 7 parameters that showed that the water of Lake Menjer could be used for fishing activities

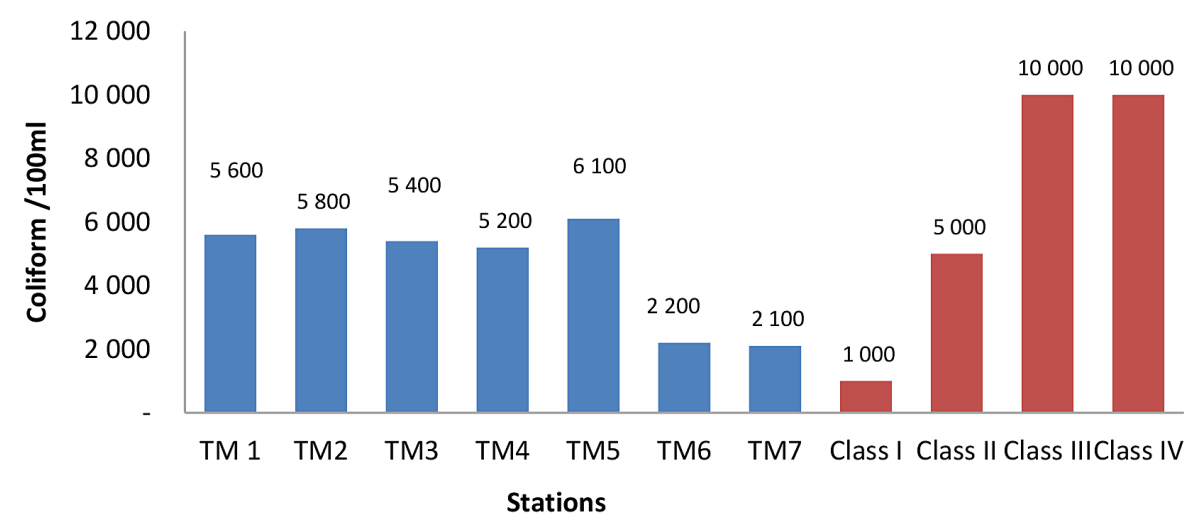

Figure 8. Distribution of coliform compared to water quality standard 
Table 4. The measurement of water quality compared water quality standards

\begin{tabular}{|c|c|c|c|c|c|c|c|}
\hline \multirow{2}{*}{ No } & \multirow{2}{*}{ Parameter } & \multirow{2}{*}{ Unit } & \multirow{2}{*}{ Conc. } & \multicolumn{4}{|c|}{ Quality status } \\
\cline { 5 - 8 } & & & & Class I & Class II & Class III & Class IV \\
\hline 1 & TSS & $\mathrm{mg} / \mathrm{l}$ & 165.62 & No & No & Yes & Yes \\
\hline 2 & BOD & $\mathrm{mg} / \mathrm{l}$ & 4.89 & No & No & Yes & Yes \\
\hline 3 & COD & $\mathrm{mg} / \mathrm{l}$ & 23.67 & No & No & Yes & Yes \\
\hline 4 & DO & $\mathrm{mg} / \mathrm{l}$ & 3.72 & No & No & Yes & Yes \\
\hline 5 & TN & $\mathrm{mg} / \mathrm{l}$ & 10.01 & No & No & Yes & Yes \\
\hline 6 & TP & $\mathrm{mg} / \mathrm{l}$ & 0.25 & No & No & Yes & Yes \\
\hline 7 & Coliform & $/ 100 \mathrm{ml}$ & $10.16 \times 10^{5}$ & No & No & Yes & Yes \\
\hline
\end{tabular}

(Class III) and irrigation (Class IV) or other designations which requires the same water quality as those uses. Those parameters are TSS, BOD, COD, DO, Total N, Total P and Total Coliform.

\section{CONCLUSIONS}

The status of water quality was at a moderately polluted level and only functions for the needs of category 3 , i.e. for freshwater fish cultivation, for irrigating plants, and or other purposes. Therefore, it was necessary to manage the Menjer Lake to improve its water quality.

\section{Acknowledgments}

The author expresses his gratitude to Jenderal Sudirman University (LPPM Unsoed) which has provided research funding through the Grant Scheme of Applied Research in 2021 with Decree No. 1067/UN23/HK.02/2021.

\section{REFERENCES}

1. Alfionita A.N.A., Patang, Kaseng E.S. 2019. Effect of eutrophication on water quality in the Jeneberang River. Journal of Agricultural Technology Education, 5, 9-23.

2. Amalia D.Y., Sudarmadji. 2016. Evaluation of the service life of Menjer Lake, which functions as a garung hydroelectric power plant in Wonosobo Regency, Central Java Province. Indonesian Earth Journal, 5, 1-10.

3. Anas P, Jubaedah I., Sudino D. 2017. Water quality and wastewater load of floating net cages in Jatiluhur Reservoir of West Java. Jurnal Penyuluhan Perikanan dan Kelautan, 11(1), 35-47.

4. Azizah D. 2017. Environmental quality assessment of Tanjungpinang Bay Waters, Riau Islands
Province. Journal of Maritime Dynamics, 6, 47-53.

5. Christiana R., Anggraini I.M., Syahwanti H. 2020. Analysis of water quality and quality status and pollution burden of the Mahap River in Sekadau Regency, West Kalimantan. Serambi Engineering Journal, 5, 941-950.

6. Daroini T.A., Arisandi A. 2020. Analysis of BOD (Biological Oxygen Demand) in the waters of Prancak Village, Sepulu District, Bangkalan. Juvenil, 1, 558-566.

7. Indonesian government. 2009. Law of the Republic of Indonesia Number 32 of 2009 concerning Environmental Protection and Management. State Gazette of the Republic of Indonesia Year, State Secretariat. Jakarta.

8. Indonesian Government. 2001. Government Regulation of the Republic of Indonesia Number 82 of 2001 concerning Water Quality Management and Water Pollution Control. State Gazette of the Republic of Indonesia Year, State Secretariat. Jakarta.

9. Kumalasari D.A., Soeprobowati T.R., Putro S.P. 2015. Phytoplankton composition and abundance in Menjer Lake, Wonosobo. Biology Journal, 4, 53-61.

10. Lihawa F., Mahmud M. 2017. Evaluation of water quality characteristics of Limboto Lake. Journal of Natural Resources and Environmental Management, 7, 260-266.

11. Minister of the Environment. Decree of the State Minister of the Environment Number 115 of 2003 concerning Guidelines for Determining the Status of Water Quality. Copy of the Deputy Minister of Environment for Environmental Policy and Institutions.

12. Mokodompit M.S.P., Umboh J.M.L., Pinontoan O.R. 2020. Lake water quality test based on escherichia coli and total coliform content in Mooat Lake, East Bolaang Mongondow Regency in 2019. Journal of KESMAS, 9, 27-32.

13. Muthifah L., Nurhayati, Utomo K.P. 2018. Water quality analysis of Lake Kandung Suli, Jongkong District, Kapuas Hulu Regency. Journal of Wetland Environmental Technology, 6, 1-10. 
14. Nurfatimah F.M., Afu L.O.A., Pratikino A.G. 2019. Distribution of surface suspended solid (TSS) in the waters of Wawatu Village, North Moramo District, South Konawe Regency. Sapa Laut Journal, 4, 123-126.

15. Nopiantari N.P.V., Arthana I.W., Astarini I.A. 2017. Impact of agricultural activities on eutrophication levels and types of phytoplankton in Buyan Lake, Buleleng Regency, Bali Province. Ecotrophic, 11, 47-54.

16. Purboseno S. 2014. Water balance simulation model in environmental economic perspective as an effort to maintain the sustainability of water resources system case study of Lake Rawapening Watershed. MSc Thesis, Diponegoro University.

17. Piranti A.S., Rahayu D.R., Waluyo G. 2018. Evaluation of Rawapening Lake's water quality status. Journal of Natural Resources and Environmental Management, 8, 151-160.

18. Piranti A.S., Wibowo D.N., Rahayu D.R.U.S. 2021. Nutrient determinant factor of causing algal bloom in tropical lake (Case study in Telaga Menjer Wonosobo Indonesia). Journal of Ecological Engineering, 22(5), 156-165. https://doi. org/10.12911/22998993/135863

19. Putri F.D.M., Widyastuti E., Christiani. 2014. Comparison of total nitrogen and total phosphorus with the abundance of chrysophita in Panglima Besar Soedirman Reservoir Waters, Banjarnegara. Scripta Biologica, 1, 96-101.
20. Pujiastuti P., Ismail B., Pranoto. 2013. Quality and pollution burden of Gajah Mungkur Reservoir. Ecoscience Journal, 5, 59-75.

21. Rahayu Y., Juwana I., Marganingrum D. 2018. Study of calculation of river water pollution loads in the cikapundung watershed (DAS) from the domestic sector. Green Engineering Journal, 2, 61-71.

22. Santoso A. D. 2018. Performance of DO, BOD, and COD values in ex-coal mining lake case study on Sangatta North Lake PT. KPC in East Kalimantan. Journal of Environmental Technology, 19, 89-96.

23. Soliha E., Rahayu S.Y.S., Triastinurmiatiningsih. 2016. Water quality and plankton diversity in Lake Cikaret, Cibinong, Bogor. Ecology, 16, 1-10.

24. Suharto B., Dewi L., Mustaqiman A.N., Marjo T.R.A.K. 2019. The study of water quality status in the Ngebrong River with physical and chemical parameter in the Tawangsari Barat Region, Pujon District, Malang Regency. Indonesian Journal of Urban and Environmental Technology, 2, 164-180.

25. Sumampouw O. Diarrhea T. 2017. An Overview of the Public Health Sector. Publisher: Deepublish (CV Budi Utama Publishing Group). Yogyakarta.

26. Tatangindatu F., Kalesaran O., Rompas R. 2013. Study of physical and chemical parameters of water in fish cultivation areas in Lake Tondano, Paleloan Village, Minahasa Regency. Journal of Aquaculture, $1,8-19$. 